\title{
CHARACTERIZATION AND ORGANIC COMPOUNDS IN PELOIDS FROM MONGOLIA
}

\author{
G.Dolmaal Sh.Tserenpil ${ }^{1}$, O.Ugtakhbayar ${ }^{1}$, S.G. Shevchenko², L.V. Kliba', M.G.Voronkov² \\ ${ }^{I}$ The Institute of Chemistry and Chemical Technology of MAS 13330 Peace avenue, MAS4 th building. Bayan- \\ zurkh district, Ulaanbaatar, Mongolia \\ ${ }^{2}$ Institute of Chemistry Siberian Branch of RAS, Irkutsk 64144, Russia \\ Contact address: 'The Institute of Chemistry and Chemical Technology of MAS 13330 Peace avenue, MAS4th \\ building. Bayanzurkh district, Ulaanbaatar, Mongolia, \\ E-mail address:dolmaal@yahoo.com
}

\begin{abstract}
The peloids are the important natural remedy all over the world. The physicochemical properties and some organic matters of peloids from 12 lakes in Mongolia were examined. These peloids belong to the continental hydrosulfide sticky peloid except Gurvan nuur peloid. Peloid from Lake Gurvan nuur was classified as a sapropel with high ash content.

The peloid organic matters were investigated using chemical analysis and several analytical techniques, such as IR, and ${ }^{13} \mathrm{C}$ NMR spectroscopy, GC/MS, gas chromatography. The concentration of total organic carbon in all continental hydrosulfide sticky peloids is ranged from $0.4 \%$ to $3.1 \%$, but $15.3 \%$ in the sapropel. It shows that the majority of the peloids in Mongolia are hydrosulfide sticky peloid with lower organic matters than the sapropel and peat. In this study, no significant difference of chemical composition was observed between dissoluble and insoluble organic matters from peloids. Some classes of biomolecules, including lipid and carbohydrate, were identified. Biogenic stimulator humic acid (HA) is the major part of the peloid organic matter. HA concentration varied between $11.2 \%$ and $55.9 \%$ of total organic matter of peloids. The macromolecule of the sapropel HA exhibited a lower aromatization degree and more functional groups than other HAs, as revealed by the " $\mathrm{C} N M R$ data and $\mathrm{C} / \mathrm{H}$ ratio. The genesis of peloid organic matter is discussed in this paper.

Our results suggest that the presence of known bioactive organic compounds, such as humic acid, lipid, and carbohydrate, as well as hydrogen sulfide causes the balneological value of peloids in Mongolia.
\end{abstract}

Keywords: lake; organic matter; peloid 


\section{Introduction}

Peloids are a multi-component system, which consists of mineral water, clay minerals, organic matter and organo-mineral complex, and applied for healing procedure. In 1807, the first chemical analysis of peloids was performed by French chemist Desser (Ivanov and Malakhov, 1963).Various types of peloids differ in concentration of organic matter and its composition. Recently, the use of healing mud in pharmaceutical formulations, spas and aesthetic medicine increased due to increasing interest and success of natural remedies (Veniale et al., 2007). Nowadays, manmade peloids that obtained by mixing mineral water and clay (Veniale et al., 2004), as well as maturated peloids after its application for therapy are widely used in many sanatoriums (Veniale et al., 2007). In this text, the term peloid refers to the natural healing mud, which is collected from the lake-bottom.

According to the conventional point of view, the therapeutic action of peloids is due to their thermal-, chemical- and mechanical properties, and hence, the thermal behavior of clay materials has been intensively studied (Cara et al., 2000; Legido et al., 2007; Ferrand and Yvon, 1991). During pelotherapy, a certain part of chemical components penetrate the skin by diffusion and electrophoresis. This concept had been demonstrated by using the Franz-type diffusion cells (Tateo et al., 2009). The mechanical particles in peloid induce mechano receptors in derma, which cause the recipient to experience the thermal and chemical effects (Vaisfeld and Galina., 1996). However, this is a limited approach to understanding the healing effects of peloid and usually emphasizes it due to heat. A lack of the fundamental research material of peloids in Mongolia results in scarce scientific background in the peloid application.

Russian scientists carried out extensive research on the chemical nature and therapeutic properties of the sapropel and peat (Bakhman and Ovsyanikova, 1965; Puntus, 1998, 2008; Shinkarenko and Milenina, 1981; Shustov, 1996). There are many biogenic stimulators produced from peloids, including Peloisilt, Peloidodistillate, Torfotum, Humisol, as well as other medical preparations based on peloid organic and inorganic fractions (Mashkovsky, 1993).

Organic matter represents $82-94 \%$ of peat, $15-80 \%$ of sapropel, $1-5 \%$ of hydrosulfide sticky mud and less than $0.5 \%$ of pseudo-volcanic mud (Ivanov and Malakhov, 1963; Tsarfis and Kiselev, 1990). Humic acid (HA) is a major part of peloid organic matter. In sapropel, HA stimulate the macrophage defense reaction, promote nervous tissue regeneration, stimulate tissue reparation, and produce anti-inflammatory effect in case of tissue burns and cornea diseases (Degtyarenko and Mokulkin, 1997). In addition, HA is the known complexing ligand of trace elements, this is also possible to form complexes with amino acids, peptides, carbohydrates and steroids, which may be responsible for some of the effects occurring in tissues, including the elimination of heavy metals, desmutagenic effects, antioxidant and anticoagulant activity.

There are more than 40 lakes with healing mud in Mongolia. The physiochemical characteristics and chemical nature of peloid may be differ due to their various origins and 
healing effects. The study of the organic matters from hydrosulfide sticky peloid is poorly addressed. The geochemical and mineralogical composition, the radioactivity of several natural nuclides of the analyzed peloids, and trace element concentration in the organic extracts were investigated earlier (Tserenpil, 2005).

The main objective of this paper is to determine the chemical composition of organic matters from natural healing mud in Mongolia, and to provide some fundamental data which are useful to explain the therapeutic effects of peloid. On the other hand, it is necessary to define their chemical composition, particularly, organic matters for peloid maturation process. This process is strongly influenced by microbial activities and the availability of organic components (Carretero et al., 2006; Tateo et al., 2009).

\section{Materials and methods}

\subsection{Sampling area}

Peloid samples were collected from 12 lakes located in Central, Eastern and Western provinces of Mongolia, including the following: Lake Avagra toson (geographic coordinates are $\left.43^{\circ} 13^{\prime} \mathrm{N} ; 109^{\circ} 31^{\prime} \mathrm{E}\right)$ and Lake Gurvan nuur $\left(42^{\circ} 01^{\prime} \mathrm{N} ; 111^{\circ} 40^{\prime} \mathrm{E}\right.$ ) (in Khentii

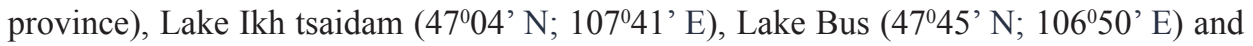
Lake Olziit (46 $58^{\prime}$ N; $106^{0} 50^{\prime}$ E) (in Central province), Lake Zegstei (in Sukhbaatar province), Lake Utaat mijuur (48 $43^{\prime} \mathrm{N} ; 115^{\circ} 05^{\prime} \mathrm{E}$ ) and Lake Hotont (in Dornod), Lake Uud (46 20 ' N; $101^{0} 14^{\prime}$ E) (in Bayankhongor), Khujirt (in Uvurkhangai), Lake Darday (49 $39^{\prime}$ N; $106^{\circ} 02^{\prime}$ E) and Lake Shargiin tsagaan (in Selenge province).

Peloids from Lake Avarga toson, Uud and Khujirt are used in the sanatoriums by preparing a mixture of mud and natural mineral water called-Rashaan.

\subsection{Methods}

Sediments were collected separately into pre-cleaned wide-mouth glass bottles of 500-1000 $\mathrm{ml}$ volume and lake surface water was retained at the top to prevent an oxidation of sediments. The sediments were refrigerated $\left(4^{\circ} \mathrm{C}\right)$ at laboratory until analysis.

The characteristics of peloids were determined according to Shukarev method (Bakhman and Ovsyanikova, 1965). Data were normalized to dry weight after desiccation at $105^{\circ} \mathrm{C}$, until weight stabilization. Biogenic silica was measured by spectrophotometer after samples were digested in a $2 \mathrm{M} \mathrm{Na}_{2} \mathrm{CO}_{3}$ solution at $85^{\circ} \mathrm{C}$ for 5 hours in plastic vessels. For the determination of dissolved sulfide, sulfide was first volatilized adding acid by converting it to gaseous hydrogen sulfide $\left(\mathrm{H}_{2} \mathrm{~S}\right) . \mathrm{H}_{2} \mathrm{~S}$ was purged from samples by carbon dioxide and trapped in an iodine solution, which was reduced by hydrogen sulfide. Sodium thiosulfate was used as a titrant to verify the sulfide concentration iodometrically. The concentration of total organic carbon (TOC) was determined using rapid dichromate oxidation of organic matter (Nelson and Sommers, 1996). The concentration of total organic matter $(\mathrm{TOM})$ was evaluated by $\mathrm{TOM}=\mathrm{TOC} \cdot 1.72$ equation. The pore water was 
separated from peloids by a simple pressing device.

Distilled water and organic solvents were used for extraction of organic matter. The solvents were evaporated by a rotary vacuum evaporator. $\mathrm{HCl}$ was used to release the organic matters associated with carbonate minerals. The lipid fraction was extracted with a mixture of chloroform/ethanol (1:1) (Dolmaa et al., 2004). Humic acid (HA) was extracted with $0.2 \mathrm{~N} \mathrm{NaOH}$ aqueous solution after demineralization of peloid. The carbohydrate extract was obtained by water extraction at $40-50^{\circ} \mathrm{C}$ and purified using a dialysis bag. The extract was freeze-dried for future analyses. This study involved identification of the different fractions of organic matter from peloids by IR and ${ }^{13} \mathrm{C}$ NMR spectroscopy, GC/MS, gas and gel chromatography. IR spectra were recorded on spectrometer IR-20 using a $\mathrm{KBr}$ pellet. GC/MS, of the organic extracts of peloid, are taken on HP 5971 A mass spectrometry using capillary columns packed with BD5, OV70-280, SE-54, and SE-30 25 or $60 \mathrm{~m}$ long in a automatically programmed temperature schedule at $4 \mathrm{~K} / \mathrm{min}$. Individual organic compounds were identified with reference to standard electronic libraries of mass spectra (chromatographic retention indices): NIST 21, NIST 98, NIST 107, PMW tox 3 , Wiley 229 , Wiley 138 , and NBS $75 \mathrm{~K}$. Spectra with at least $85 \%$ similarity were chosen. For dialkyl phthalates identification we selected spectra with a resemblance coefficient no lower than $95 \%$. ${ }^{13} \mathrm{C}$ NMR spectra were acquired on spectrometer Varian VXR 500S with working frequency of $125.1 \mathrm{MHz}$ for nuclei ${ }^{13} \mathrm{C}$ in solution dimethyl sulfoxide, mode INVGAT and time of scanning 24 hours. For the identification of monosaccharide composition, we used gas-liquid chromatography. Trichloroacetic acid was used for protein analysis as a precipitating agent.

\section{Results}

\subsection{The general characteristics of peloids}

The physicochemical characteristics of sampled peloids are reported in Table 1. Based on their properties, peloids were classified by the national standard (Dolmaa et al., 2008) due to the lack of normative regulations about quality standards and non-existing international classification for peloids (Veniale et al., 2004). The moisture content varied from 10.48 to $55.95 \%$, which was lower compared to organic rich peloids $(60-80 \%)$. Most peloids are dense 1.43-1.9 g/ $\mathrm{cm}^{3}$ (excluding those from Gurvan nuur), and healing materials for pelotherapy may be prepared by mixing with mineral water. The concentrations of TOM were usually lower than the peat and sapropel, but higher than pseudo-volcanic peloid. For instance, TOM concentration varied between $0.74-5.4 \%$ in peloid samples, while the concentration was $26.32 \%$ in peloid from Gurvan nuur. Peloid $\mathrm{H}_{2} \mathrm{~S}$ level was high (up to $0.89 \%$ ) and resembles to the concentration for continental hydrosulfide sticky peloids.

From Table 1, the studied healing muds are typical of the continental hydrosulfide sticky peloids (except peloid from Lake Gurvan nuur) and were classified into the following subgroups based on by mineralization and sulfidation. Peloids from Lake Olziit, 
Khotont and Lake Ikh tsaidam were highly mineralized (pore water mineralization was 67.8-215.5 g/L) and medium sulfidation type, Lake Zegstei, Bus, Darday and Khujirt's peloids are low mineralized (15.8-19.7 g/L) and high sulfidation; peloids from Lake Avarga toson and Utaat minjuur are low mineralized (10.7-12.1 g/L) and low sulfidation. Peloid from Lake Gurvan nuur dramatically differed from other mud samples in moisture content $(55.95 \%)$, high concentration of TOC (15.30\%), lower content of particles with diameter more than $0.25 \mathrm{~mm}(0.46 \%)$, and pore water mineralization $(3.8 \mathrm{~g} / \mathrm{L})$. The results indicate that Gurvan nuur peloid was formed in low-mineralized water and therefore was classified as sapropel peloid with high ash content (67.46\%).

Table 1.

The general characteristics of peloids in Mongolia

\begin{tabular}{|c|c|c|c|c|c|c|c|c|}
\hline \multirow[b]{2}{*}{ Peloids from Lake } & \multirow[b]{2}{*}{ 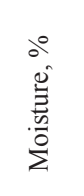 } & \multirow{2}{*}{ 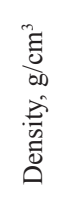 } & \multirow{2}{*}{ 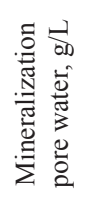 } & \multicolumn{5}{|c|}{ Content, \% (dry weight, dw) } \\
\hline & & & & TOC & TOM & $\mathrm{Si}_{\text {bio }}$ & 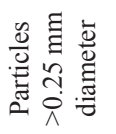 & $\tilde{\mathscr{I}}^{N}$ \\
\hline Avarga toson & 37.84 & 1.55 & 10.7 & 2.83 & 4.87 & 0.45 & 4.72 & 0.03 \\
\hline Bus & 44.65 & 1.53 & 16.0 & 3.14 & 5.40 & 0.50 & 5.25 & 0.89 \\
\hline Darday & 45.47 & 1.43 & 19.3 & 0.43 & 0.74 & 0.09 & 15.77 & 0.21 \\
\hline Ikh tsaidam & 33.60 & 1.75 & 140.6 & 1.30 & 2.24 & 0.15 & 14.78 & 0.30 \\
\hline Gurvan nuur & 55.95 & 1.13 & 3.8 & 15.30 & 26.32 & 0.87 & 0.46 & 0.05 \\
\hline Khotont & 32.58 & 1.65 & 67.8 & 0.91 & 1.57 & 0.62 & 7.86 & - \\
\hline Khujirt & 27.60 & 1.78 & 19.7 & 2.15 & 3.70 & 1.07 & 1.97 & 0.24 \\
\hline Olziit & 29.06 & 1.90 & 215.5 & 1.06 & 1.82 & 0.26 & 3.28 & 0.25 \\
\hline Utaat minjuur & 27.14 & 1.73 & 12.1 & 2.44 & 4.20 & 0.49 & 24.82 & 0.03 \\
\hline Uud & 37.87 & 1.74 & 163.9 & 2.60 & 4.47 & 0.04 & 9.80 & 0.86 \\
\hline Shargiin tsagaan & 10.48 & 1.64 & 58.7 & 1.27 & 2.18 & 0.13 & 2.50 & 0.03 \\
\hline Zegstei & 26.99 & 1.73 & 15.8 & 0.62 & 1.07 & 0.08 & 5.66 & 0.21 \\
\hline
\end{tabular}

$\mathrm{H}_{2} \mathrm{~S}$ possesses important physiological and pharmacological functions in the regulation of blood pressure (Rui Wang., 2002), and its content varied between 0.03 and $0.89 \%$ in dry peloids. The increase in the availability of reactive organic matter promotes $\mathrm{H}_{2} \mathrm{~S}$ formation through anoxic bacterial reduction of salt water sulfate (Allison et al., 1991). This positive correction between organic matter and sulfide was also observed in these lakes, with higher organic content associated with higher sulfide (Table 1). The maximum concentrations of $\mathrm{H}_{2} \mathrm{~S}$ were $860 \mathrm{mg}$ and $890 \mathrm{mg} / 100 \mathrm{~g}$ peloid in Lake Uud and Bus, respectively. The TOM concentrations were $4.47 \%$ and $5.4 \%$ in above mentioned peloids.

\subsection{Dissoluble and insoluble organic matters from peloid}

Dissoluble organic matter (DOM) and insoluble organic matter (IOM) isolated from peloids ranged from $0.37-15.51 \mathrm{mg} / \mathrm{g}$ and $0.84-12.93 \mathrm{mg} / \mathrm{g}$, respectively (Table 2). The distribution and bruto-formula of individual organic compounds in DOM and IOM are summarized in Table 3. 
GC/MS chromatogram of dissoluble organic matter (DOM) from peloids in Lake Avarga toson is shown in Fig.1. DOM of peloids was comprised of $58.38-66.67 \% \mathrm{C}$, $6.55-9.89 \% \mathrm{H}, 0-1.83 \% \mathrm{~N}$, and $0-4.05 \% \mathrm{Cl}$ (Table 2) which indicated the presence of heteroatom compounds in the organic extracts. The hydrocarbons were minor constituents (0.52-4.66\%) in DOM from lakes Avarga toson, Ikh tsaidam, Utaat minjuur, Uud, whereas its concentration ranged between $16.13-57.31 \%$ in the extract from Lake Darday, Gurvan nuur, Zegstei, and Bus (Table 3).

Table 2.

The concentration and elemental composition of DOM and IOM

\begin{tabular}{l|c|c|c|c|c|c}
\hline \multirow{2}{*}{ Lake } & \multirow{2}{*}{$\begin{array}{c}\text { DOM, mg/g } \\
\text { peloid }\end{array}$} & \multirow{2}{*}{$\begin{array}{c}\text { IOM,mg/g } \\
\text { peloid }\end{array}$} & \multicolumn{3}{c}{ Elemental composition of DOM, \% } \\
\cline { 5 - 7 } & Avagra toson & 11.57 & 62.65 & 9.89 & 0.26 & 3.32 \\
Bus & 5.23 & - & 58.38 & 8.79 & 1.83 & 2.78 \\
Gurvan nuur & 2.83 & 12.93 & 66.05 & 6.25 & 1.57 & 0.07 \\
Darday & 7.73 & 4.84 & 59.66 & 7.05 & 1.83 & 1.18 \\
Ikh tsaidam & 1.43 & 1.77 & 63.10 & 8.47 & 0.00 & 0.00 \\
Olziit & 2.24 & 1.46 & 61.70 & 9.18 & 0.35 & 0.00 \\
Utaat minjuur & 1.83 & 1.22 & 65.18 & 6.55 & 0.00 & 4.05 \\
Uud & 15.51 & 12.86 & 60.57 & 6.89 & 0.52 & 2.58 \\
Khotont & 7.11 & 4.23 & 58.38 & 7.58 & 0.32 & 3.48 \\
Khujirt & 0.93 & 2.76 & 61.20 & 9.04 & 1.83 & 1.95 \\
Shargiin tsagaan & 3.88 & 1.26 & 66.67 & 8.20 & 0.00 & 2.64 \\
Zegstei & 0.37 & 0.84 & 58.48 & 8.77 & 1.58 & 3.58 \\
\hline
\end{tabular}

The straight-chain $\mathrm{C}_{14}-\mathrm{C}_{26}$ alkanes were distributed in most DOM from peloids, but the predominance of even- or odd carbon number hydrocarbons was not observed. The sedimentary odd carbon number n-alkanes with short chains indicated algal input, while long chain alkanes represented contributions from terrestrial plants (Eglinton and Hamilton). Only one sample from Zegstei contained elevated levels of long chain alkanes $\mathrm{C}_{29}-\mathrm{C}_{43}$ appears $9.5 \%$. Alkenes and monocyclic hydrocarbons $(0.3-7.4 \%)$ were found in several peloids. Polycyclic aromatic hydrocarbons, which originated from anthropogenic sources, were not observed. In peloids from Lake Khujirt, Bus and Gurvan nuur the concentration of carboxylic acid varied $1.09 \%, 7.47$, and $14.46 \%$, respectively, while their esters ranged from $9.55-26.09 \%$ in DOM from Lake Zegstei, Khotont, and Gurvan nuur (Table 3). 


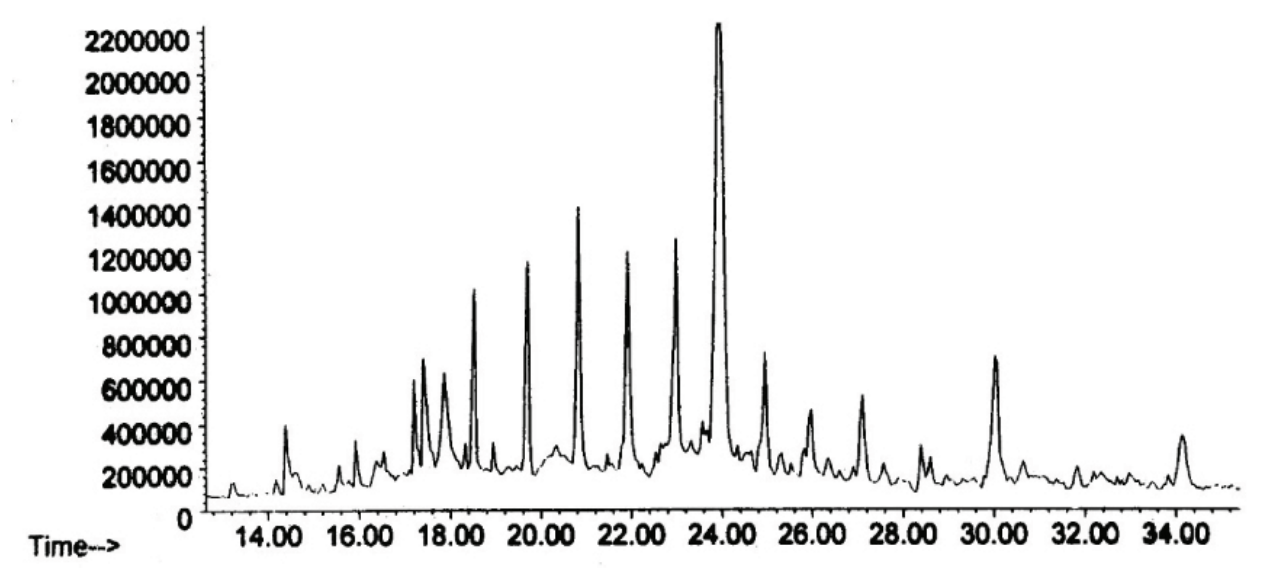

Fig.1. Mass chromatogram of DOM isolated from peloid in Lake Avarga toson

Saturated and unsaturated hydrocarbons were abundant in insoluble organic matter (IOM) of peloids from Lake Darday, Zegstei, Utaat minjuur, and Ulziit (18.99\%, 28.76\%, $74.8 \%$ and $76.01 \%$, respectively). As shown in Table 3, IOM extracts contain carboxylic acids 1.62-29.25\% (except Lake Uud and Ulziit), and their esters 2.55-8.69\%. Silicon organic compound (hexaethylcyclotrisiloxsane; tetra ethyl silan, Ethyleneglycolbis(triethylsilyl) ether; 1'-O-hexsanoylsucrose) was identified in IOM from Lake Khotont, Dornod province. Organic silicon is an active component that participates, for instance, in the formulation of some antihomotoxic homeopathic medicines (Gomes et al., 2007). Therefore, biogenic silica that originates from the production of dissolved silica was quantified 0.62 $\%(\mathrm{Si})$ in Khotont peloid (see Table 1). 


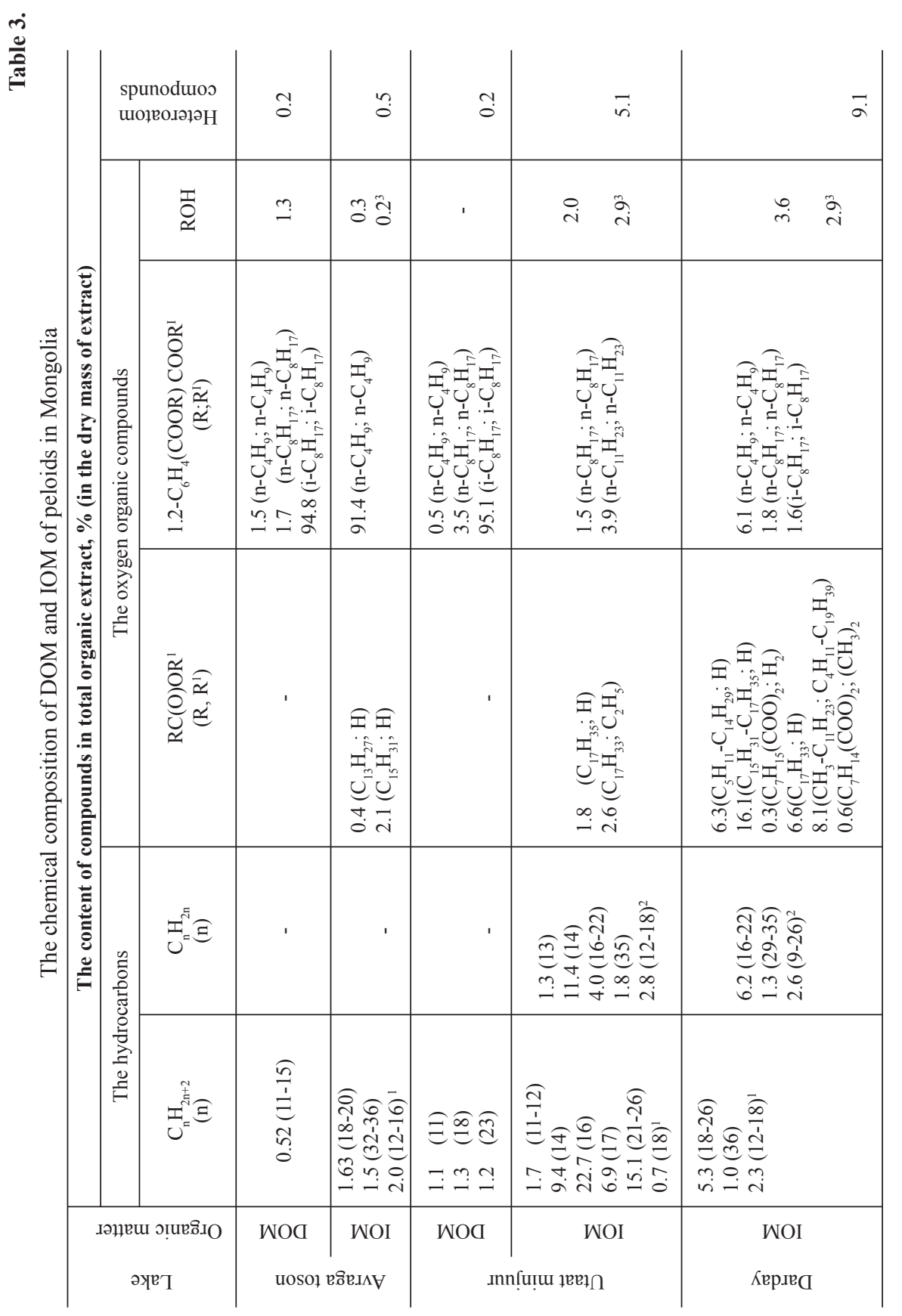

-10 - 


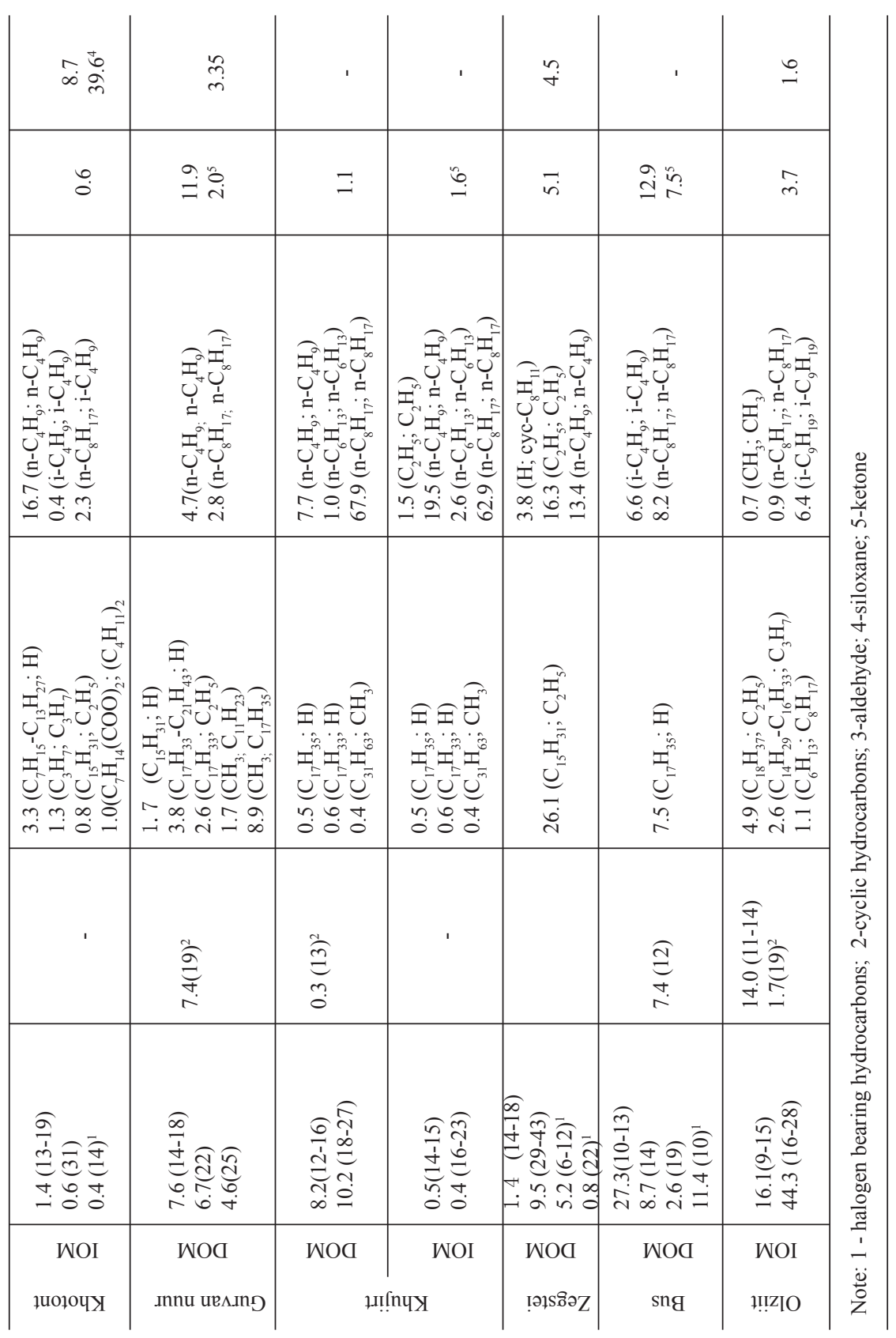


Insignificant amounts of alcohol, aldehyde, ketones and heteroatom compounds were observed in most of DOM and IOM fractions. Elevated concentrations (totally) of alcohol, aldehyde and ketone were 13.9 and 20.4\% in Gurvan nuur and Bus peloids, respectively. The distribution individual organic compounds was very complex, and no relationship was observed between DOM and IOM composition.

Dialkyl phthalates (with various alkyl substitutes) were found in both DOM and IOM fractions as shown in Table 3. The range for peloid DAP concentration was comparatively high (3.3-99.1\%). There was no relationship between their abundance and concentration of TOM in peloids. Dibityl- and dioctyl phthalates were more abundant than other DAPs. A high fraction of DAPs were observed in both DOM and IOM from Avarga toson peloid (91.4\% and $94.76 \%$, respectively).

\subsection{Lipid}

Lipid concentrations were $0.1-2.2 \mathrm{mg} / \mathrm{g}$ in dry hydrosulfide peloids, but elevated concentrations were appear $(2.9 \%)$ in the sapropel. The chemical composition of lipid was further studied by GC/MS. From Table 4, hydrocarbons (16.0-41.2\%), carboxylic acids $(0-1.9 \%)$, esters of aliphatic acids (16.7-53.3\%) and steroids $(9.3 .6 \%)$ were dominant in lipid from the hydrosulfide peloid. n-Alkanes from $\mathrm{C}_{16}$ to $\mathrm{C}_{25}$ were more abundant among the lipid hydrocarbons. Alkanes were detected by GC/MS on fragment ions $m / z$ $57+71+85+99+113 \ldots$. The high content of n-alkanes in lipid from marine sediments indicates that their genesis correlated with seaweed. Marine organisms such as diatomic seaweeds produce n-alkanes from $\mathrm{C}_{15}$ to $\mathrm{C}_{32}$ (Afonina, 1998). The concentration and composition of alkanes indicate their biogenic genesis.

Ethyl esters of myristic- (0-3.6\%), palmitic- (6.1-16.8\%), stearic- (3.4-7.6\%) and oleic $(0-13 \%)$ acid were investigated in peloid lipid extract. Identified zoo- and phytosteroids included cholestan-3-one; cholestan-3-ol and 22,23-dihydrostigmasterol. Also found ergosterol, which is used as an indicator of fungal biomass in sediments. The basic components of sapropel lipid are hydrocarbons (20.0\%), carboxylic acids $(9.0 \%)$ and their esters $(7.7 \%)$, steroids $(7.4 \%)$ and other oxygen containing compounds $(18.0 \%)$. 
Table 4.

The concentration of lipid and predominant compounds in the extracts from peloids

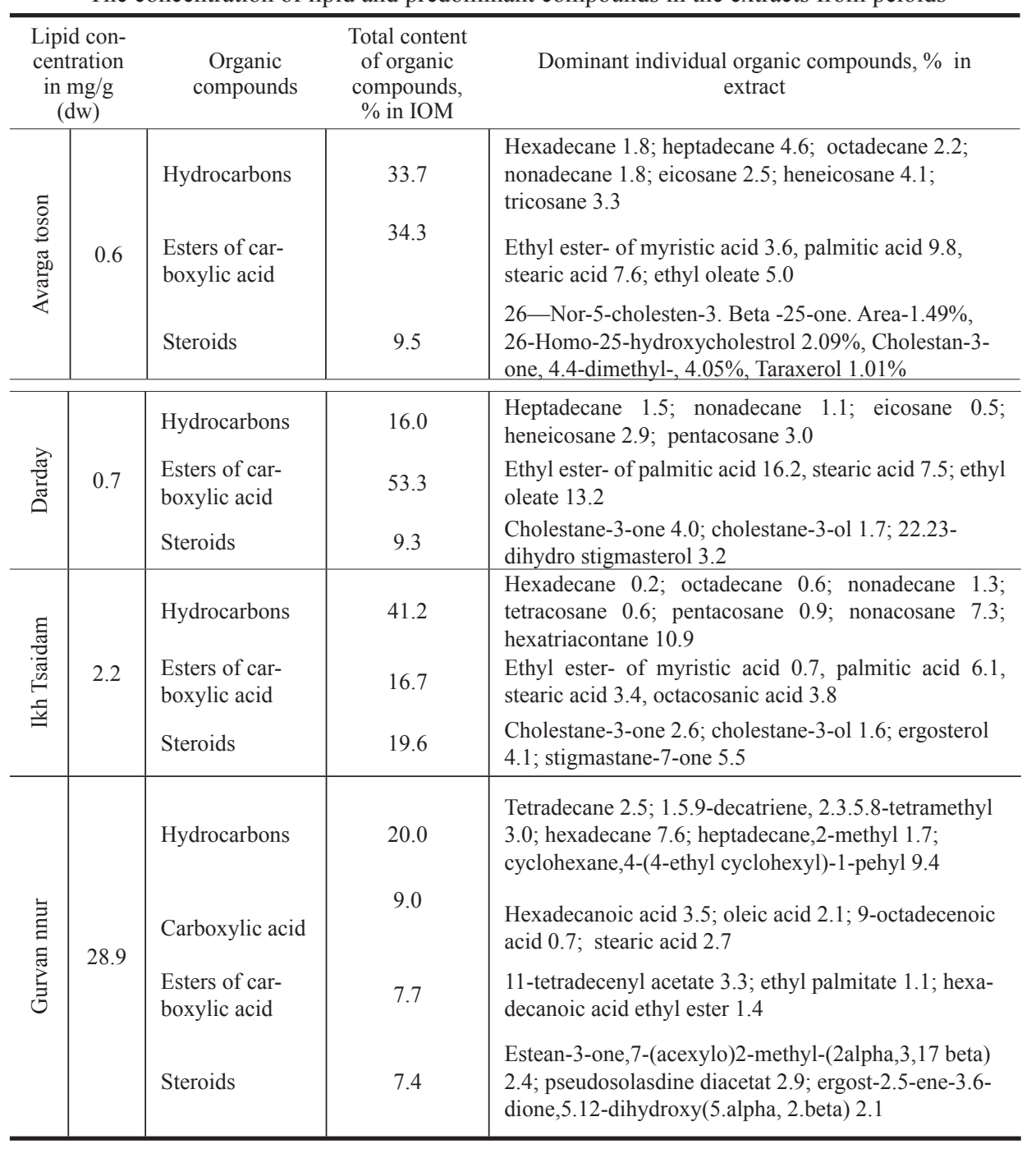

\subsection{Humic acid}

HA concentration varied from 11.2 to 55.9 percent of TOM in peloids. The highest content of HA (14.7\%) was identified in the sapropel from Lake Gurvan nuur. HA concentration $(2 \%)$ in the peloids from Lake Avarga toson, Bus and Khujirt was higher than other hydrosulfide peloids.

Further study was focused on the sapropel HA. The elemental composition of isolat- 
ed humic acid was investigated in order to obtain general information about the sapropel HA molecular structure (Table 5). The sapropel HA from Lake Gurvan nuur had lower atomic ratio $\mathrm{C} / \mathrm{H}$ (7.58) and is more aliphatic in nature than coal $\mathrm{HA}$. The $\mathrm{C} / \mathrm{N}$ ratio of the sapropel was 8.28 .

Table 5.

The elemental composition of humic acid from the sapropel

\begin{tabular}{|c|c|c|c|c|c|c|c|}
\hline \multicolumn{5}{|c|}{ Content of elements, $\%$ of HA } & \multirow{2}{*}{ Ash, \% } & \multirow{2}{*}{$\mathrm{C} / \mathrm{H}$} & \multirow{2}{*}{$\mathrm{C} / \mathrm{N}$} \\
\hline $\mathrm{C}$ & $\mathrm{H}$ & S & $\mathrm{N}$ & $\mathrm{Cl}$ & & & \\
\hline 49.27 & 6.50 & 1.45 & 5.95 & 1.32 & 6.60 & 7.58 & 8.28 \\
\hline
\end{tabular}

HA chemical properties were examined by IR and ${ }^{13} \mathrm{C}$ NMR spectroscopy. In the IR spectrum of sapropel HA, a broad intense band registered at $3440 \mathrm{~cm}^{-1}$ was assigned to $\mathrm{OH}$ and $\mathrm{NH}$ groups. The $\mathrm{C}-\mathrm{H}$ stretch of aromatic ring or alkene group appears from 3040$3100 \mathrm{~cm}^{-1}$. The intense bands at 2921 and $2954 \mathrm{~cm}^{-1}$ were assigned to the $\mathrm{C}-\mathrm{H}$ stretch of methyl- and methylene groups. The bands at 1720,1682 and $1634 \mathrm{~cm}^{-1}$ were assigned to $\mathrm{C}=\mathrm{O}$ stretch of carboxyl groups, and 1540 and $1506 \mathrm{~cm}^{-1}$ bands due to $\mathrm{C}=\mathrm{C}$ stretch in condensed aromatic systems, respectively. The 799 and $751 \mathrm{~cm}^{-1}$ bands were assigned to aromatic compounds with aliphatic side assistants.

${ }^{13} \mathrm{C}$ NMR spectrum is shown in Fig.2; a carbon atom (3.84\%) for the carbonyl group assigned to 226 and $186 \mathrm{ppm}$, and the signals at 186-175 ppm corresponded to the carbon atom $(11.19 \%)$ of carboxyl, ester, and amide.

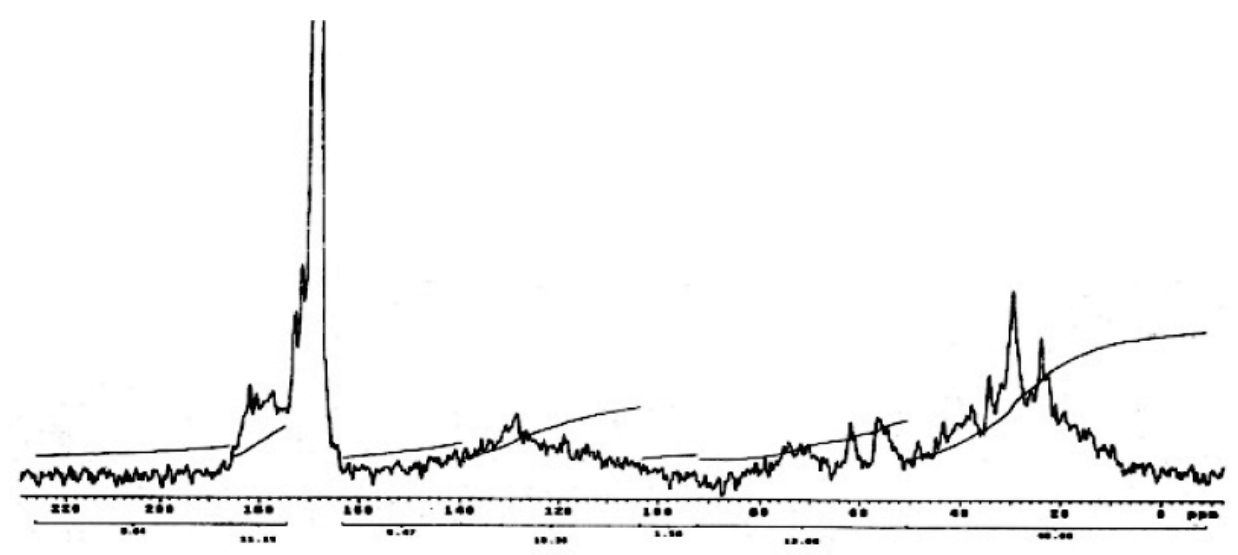

Fig.2. ${ }^{13} \mathrm{C}$ NMR spectrum of humic acid from the sapropel in dimethyl sulfoxide

The chemical shifts at $92-50$ ppm relate to the carbon atoms $(13.88 \%)$, which are found in methoxyl, alcohol, and ether groups. The integrated area of above mentioned peaks showed that sapropel HA has a more functional groups than soil and lignite HA 
(data reported by Drosos et al., 2009). The signals at 162-140 ppm, due to aromatic carbon $(5.47 \%)$ linked to the oxygen atom, at $140-106 \mathrm{ppm}$, due to aromatic carbon $(18.38 \%)$ attached to carbon or hydrogen atoms, and the signals at $0-50$ ppm due to a carbon $(45.66 \%)$ in alkyl groups. The aromaticity of HA was calculated by expressing the level of aromatic carbon as a percentage of total contents of aliphatic and aromatic carbon atoms $(28.62 \%)$, which resembled the value for HAs from river and lake sediments (Mengchang et al., 2008).

\subsection{Carbohydrate}

Carbohydrates account for a substantial amount of the dissolved and particulate organic carbon in the sediments of marine environments. Carbohydrates were isolated in peloids from Lake Darday, Ikh tsaidam, Utaat minjuur, Uud, Khujirt, and Gurvan nuur, and the concentrations were largely varied $(0.02-1.60 \mathrm{mg} / \mathrm{g}$ dry hydrosulfide peloid and $4.80 \mathrm{mg} / \mathrm{g}$ dry sapropel).

IR spectrum of carbohydrates from peloid showed a broad band at $3600-3280 \mathrm{~cm}^{-1}$ which was assigned to -OH group. The $\mathrm{O}-\mathrm{H}$ stretch of the unassociated hydroxyl group in alcohols appears as a narrow band at $3670-3580 \mathrm{~cm}^{-1}$. The $2924 \mathrm{~cm}^{-1}$ and $2855 \mathrm{~cm}^{-1}$ sharp and intense bands were assigned to valence vibrations due to $\mathrm{CH}_{2}$ group. The carbonyl stretch $\mathrm{C}=\mathrm{O}$ appears as an intense bands at $1680-1620$ and $1590 \mathrm{~cm}^{-1}$, also the $\mathrm{C}-\mathrm{O}-\mathrm{C}$ stretch in the region the $1090-1050 \mathrm{~cm}^{-1}$.

Monosaccharide composition was studied by gas chromatography. Its compositions were not largely varied in the hydrosulfide sticky muds from Lake Darday, Ikh tsaidam and Uud (Fig 3).

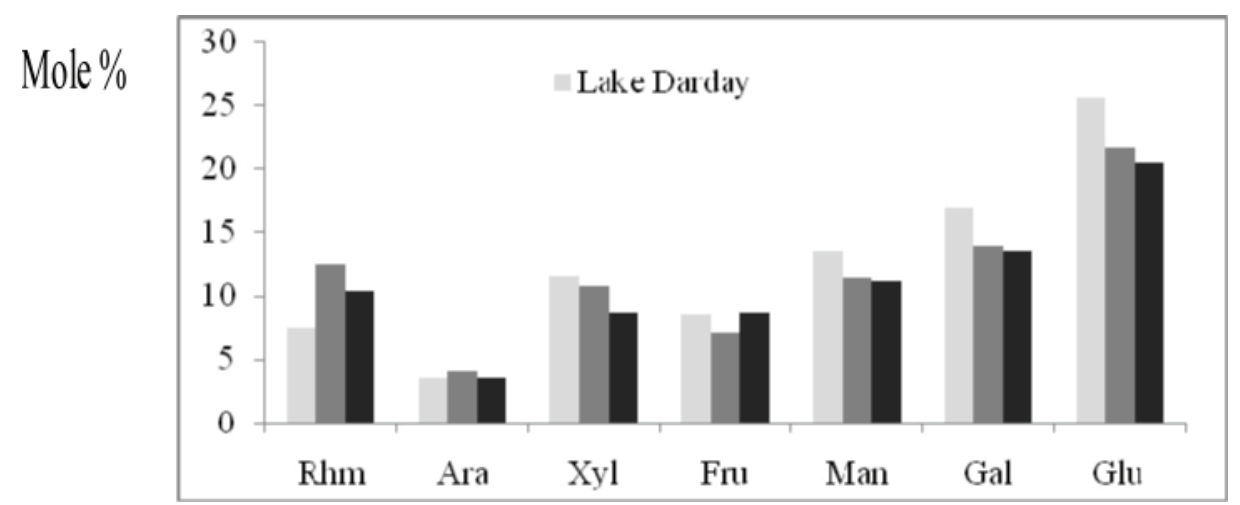

Fig 3. Monosaccharide composition of peloids from Lake Darday, Uud and Ikh tsaidam. (Rhm, rhamnose; Ara, arabinose; Xyl, xylose; Fru, fructose; Man, mannose; Gal, galactose; and Glu, glucose)

Glucose, which is present at higher levels in vascular plants, was the most abundant monosaccharide in peloid carbohydrate extract (20.48-25.52 mol\%). Galactose, xylose 
and mannose contents were $13.50-16.91 \mathrm{~mol} \%, 8.57-11.54 \mathrm{~mol} \%$ and $11.07-13.55 \mathrm{~mol} \%$; respectively. In order to verify the reliability of our data, we compared our results with values reported for marine and estuarine sediments. The concentration of total uronic acids varied between 13.12-24.07 mol\%, and those are carboxylated acidic of polysaccharides.

Free and associated carbohydrates were isolated from Gurvan nuur sapropel. Their contents were $0.27 \%, 0.21 \%$, respectively. The chemical nature of the sapropel carbohydrate was studied by the elemental analysis and molecular weight distribution. The dissoluble carbohydrate consists of $39.8 \% \mathrm{C}, 4.9 \% \mathrm{H}$ and $3.4 \% \mathrm{~N}$, insoluble carbohydrate $37.3 \% \mathrm{C}, 4.9 \% \mathrm{H}$ and $5.3 \% \mathrm{~N}$. These results showed that these fractions may contain protein. Protein was identified in both free (18.3\%) and associated (12.2\%) carbohydrate fractions by analysis.

\section{Discussion}

Peloids were classified according to their physochemical characteristics including peloid color, moisture content, dissoluble sulfides and total organic matters concentration, as well as material properties related to therapheutic appliciation (such as particles with diameter more than $0.25 \mathrm{~mm}$ and elasticity). The analyzed peloids have the smell of hydrogen sulfide, they are dark gray or black color, and possess elastic and adhesive characteristics (the latter assessed by touch). Moisture content, concentration of TOM, and hydrogen sulfide indicated the peloids from 11 lakes belonged to the contanental hydrosulfide sticky peloids. The hydrosulfide sticky peloids from Lake Avraga toson, Bus, Utaat minjuur, Uud and Khujirt are rich in organic matter (3.7-5.4\%), compared to others from the same class of peloids. In general, hydrosulfide sticky peloids formed in the mineralized water that is rich in sulfate. The increase in the availability of reactive organic matter promotes $\mathrm{H}_{2} \mathrm{~S}$ formation through anoxic bacterial reduction of salt water sulfate (Allison et al., 1991). Those two processes, including oxidation of organic matter and reduction of sulfate, are linked through the microbial ecosystem. Likewise, the level of $\mathrm{H}_{2} \mathrm{~S}$ in peloids Bus and Uud was slightly higher than the level for contanental hydrosulfide peloids (reported data by Shinkarenko and Milenina., 1981). This was likely due to their high organic content.

The sapropel from Lake Gurvan nuur in Khentii province is suggested for healing procedure of children and the elderly due to their low mineralization and high concentration of total organic matter.

A certain part of the sediment organic carbon is loosely or tightly associated with mineral particles or held together by interaction between organic molecules. Therefore, organic content may be associated with dissoluble and/or insoluble aggregates. The compositions of isolated DOM and IOM extracts were compared using GC/MS data. Major constituents were identified as hydrocarbons, carboxylic acids, aliphatic and aromatic acid esters. There were distributed saturated and unsaturated hydrocarbons with $\mathrm{C}_{12}-\mathrm{C}_{36}$ carbon atom. The distribution of carboxylic acids in DOM and IOM fractions is character- 
ized by the predominance of the odd carbon numbered compounds (maximum at $\mathrm{C}_{15}$ and $\mathrm{C}_{17}$ ), which are considered acids produced by bacterial activities in the surface sediments (Ficken et al.,2000).

DAP concentrations in dissoluble and insoluble organic matter of peloids from Lake Avarga toson, Khujirt, Zegstei and Utaat minjuur were high. All DAPs in the ion chromatogram were dominated by peak with $m / z 149$, which was due to the $\mathrm{C}_{6} \mathrm{H}_{4}(\mathrm{C}=\mathrm{O})_{2} \mathrm{O}^{+} \mathrm{H}$ ion. The mechanism of formation of fragment ion $(\mathrm{m} / z \mathrm{149})$ has been shown by the scheme in Fig.4 (Vulfson et al., 1985).

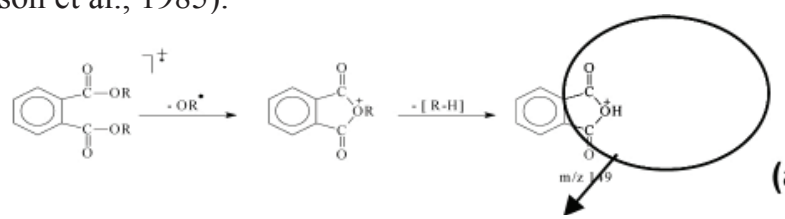

(a)

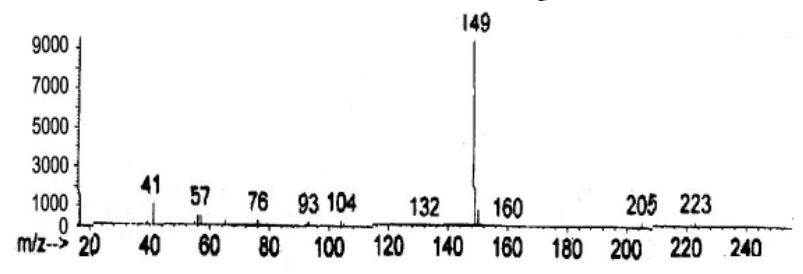

(b)

Fig.4. (a)-The mechanism of formation of $\mathrm{C}_{6} \mathrm{H}_{4}(\mathrm{C}=\mathrm{O})_{2} \mathrm{O}^{+} \mathrm{H}$ fragment ion;

(b)-mass spectrogram of bis(2-ethylhexyl)phthalate with dominated peak $m / z=149$

DAFs are used by chemical and polymeric industries as a plasticizer, therefore, DAPs in the environment are associated with anthropogenic sources (Afonina, 1998). However, the studied lakes are located far away from industrial sources and developed areas, and are not polluted according to Mongolian national tradition. Hence phthalates in organic extract from Mongolian peloids may not be from industrial products or waste.

A number of references specify that DAP is found in many plants. Recently, bis(2ethylhexsil) phthalate was found in an extract from flax cannabacea (Jamyansan, et al., 2003), o-phthalic acid and phthalates were found in greens, poppy-seed, and in the oil fraction from roots Levisticum officinalic koch (Giam et al., 1984). DAP from peloids in Mongolia probably derived from decayed remnants of plants. Higher concentration of DAPs are not very- toxic, cancerogenic or irritating to the skin (European Chemical Industry Ecology and Toxicology Centre, 1985). As a plasticizer, DAPs can be result in giving peloid's an elastic and sticky nature.

Lipid fraction isolated from geological sediments contains a broad group of naturallyoccurring molecules, which includes hydrocarbons, fatty acids and their esters, steroids, inorganic sulfur and others (Degens., 1967). Lipids penetrate through the skin more easily than water solution due to their oil solubility, and are considered anti-inflammatory (Tolomio et al., 1999; Bruno et al., 2005). 
(\%)

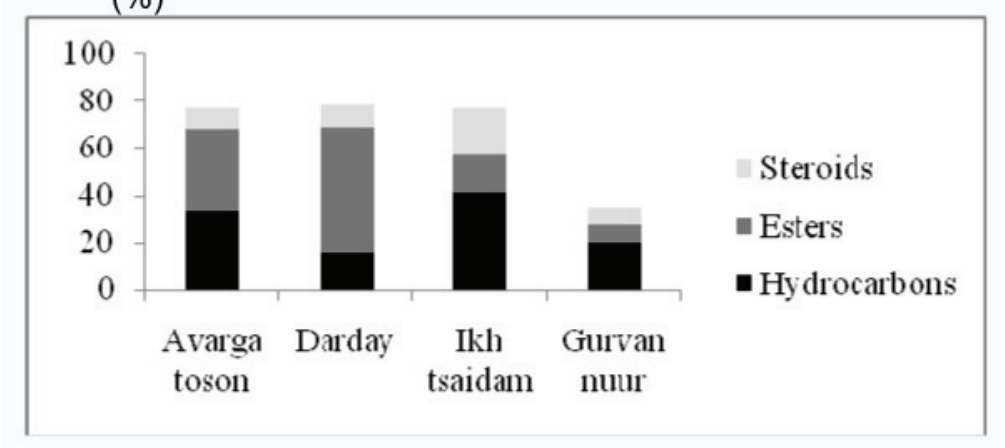

Fig.5. The predominant groups in lipid extract

The n-alkanes with carbon atom $\mathrm{C}_{16}$ to $\mathrm{C}_{25}$, esters of saturated and unsaturated fatty acids with even carbon number $\mathrm{C}_{14} \mathrm{C}_{16}, \mathrm{C}_{18}$ and $\mathrm{C}_{20}$, and cholestan-3-one; cholestan-3-ol and 22,23-dihydrostigmasterol and ergosterol were abundant in most lipid extract from peloids. Lipids from the hydrosulfide peloids contain more fatty esters and steroids than the sapropel (Figure 5).

Humic substances are not found in the tissue of living plants and animals, but they formed by secondary synthesis of microbially decomposed products from the remnant of plants and animals (Manskaya and Drozdova, 1964). Generally the microbial decomposition process is more developed in sapropel compared to hydrosulfide sticky peloids. The sapropel HA from Lake Gurvan nuur $(\mathrm{C} / \mathrm{H}=7.58)$ is more aliphatic than coal HA, which was also reported by Mengchang et al., (2008). The $\mathrm{C} / \mathrm{N}$ ratio of the sapropel was 8.28 , indicating that aquatic plants might be the dominant contributors to these humic substances (Meyers and Ishiwatari, 1993). Characterization of HA demonstrated that peloid HA was generated from the initial biomass of reservoirs, mainly from zoo- and phytoplankton (Puntus, 1998).

According to the ${ }^{13} \mathrm{C}$ NMR data the aromaticity of the sapropel HA exhibited lower (28.62\%) value as HAs from river and lake sediments (Mengchang et al., 2008), while aromaticity of coal HA varied between 39.7-62.6\% (Batuev et al., 2005). Data from this study indicated that sapropel HA differs due to lower molecular weight and high content of functional groups compared to other HAs. At present, HAs from sapropel are extensively used in manufacturing of cosmetic products.

The carbohydrates in peloids are the nourish, which enable numerous microorganisms to live and occupy the mud environment. Monosaccharide composition is a useful tool for identifying the sources of carbohydrates (Cowie and Hedges, 1984; D'Souza and Bhosle, 2001). Monosaccharide compositions did not vary in the hydrosulfide sticky muds from Lake Darday, Ikh tsaidam and Uud (Fig 5). In order to verify the reliability of our data, we compared our results with those reported in literature for the marine and estuarine sediments. Monosaccharide composition and ratios in peloids were similar to 
the reported data (Khodse et al., 2008); that is, monosaccharides may have been derived from a mixture of phytoplankton, marine bacteria and terrestrial plants.

The distribution and concentration of organic matters in peloids chiefly reflects the relative contribution of terrestrial and marine plant inputs and bacterial activity.

During pelotherapy, chemical components, including mineral cations, many essential elements, and organic compounds, are available to penetrate the human body across the skin by diffusion and electrophoresis.

\section{Conclusion}

The physicochemical characteristics and some organic matter of peloids from 12 lakes in Mongolia were investigated. The majority of the studied peloids from Mongolian lakes were classified as continental hydrosulfide sticky peloid. But peloid from Lake Gurvan nuur were classified as sapropel.

A variety of analyses were used to determine the amount and type of organic matter present in peloid samples. We isolated the organic matter (dissoluble and insoluble organic matter, lipid, humic acid, and carbohydrate) from the peloids and determined their composition. There were dominated by saturated and unsaturated hydrocarbons with $\mathrm{C}_{14^{-}}$ $\mathrm{C}_{26}$ carbon atoms, aliphatic carboxylic acids and their esters, and esters of aromatic acids in dissoluble and insoluble organic matter.

Lipid extracts from peloids were dominated by n-alkanes with $\mathrm{C}_{16}-\mathrm{C}_{25}$, esters of fatty acids and steroids. We conclude that lipid of hydrosulfide sticky peloid differs in high concentration of fatty esters and steroids from sapropel lipid. There was dominated hexose in carbohydrate extract from the analyzed peloid. The values of monosaccharide composition and ratios suggested they derived from a mixed source of phytoplankton, marine bacteria and terrestrial plants. ${ }^{13} \mathrm{C} \mathrm{NMR}$ results showed that sapropel HA has a low aromaticity than coal HA, and high content of reactive functional groups like soil HA.

Our results suggest that the presence of known bioactive organic compounds, such as humic acid, lipid, carbohydrate, protein, as well as hydrogen sulfide, may be responsible for the balneological value of peloids in Mongolia.

\section{References}

Alexeenko B.A., 2000. Ecological geochemistry. Logos, Moscow. p.235-237. (Russian) Allison, P.A., Smith, C.R., Kukert, H., Deming, J.W., Bennett, B.A., 1991. Deep-water taphonomy of vertebrate carcasses: a whale skeleton in the bathyal Santa Catalina Basin. Paleobiology 17, p. $78-89$

Afonina, T.E., 1998. The transformation of organic pollutant in water thickness and sediments, The streams of hydrocarbons in Lake Baikal, processes of their accumulation and transformation in sediments, Ph.D. Thesis, Irkutsk, Russia. p.78-89.

Bakhman, V.I., Ovsyanikova, K.A., 1965. Methods for healing mud analyses. Nauka, Moscow. (Russian) 
Batuev, B. TS., Atuev, E. V., Zoltoev, N. V., Bodoev, Bykov, I. P., Dashitsyrenova, A. D., 2005. Estimation of Physiological Activity of Humic Substances of Oxidized Coal (Buryatia). Chemistry for Sustainable Development., Vol 13, p. 501-505.

Belov A.G., 1993. In: Workshop on Application of Microtron Physics, Plovdiv, 22-24 September, 1992, D15-9380, Dubna, Moscow, p.20-25.

Cara, S., Carcangiu, G., Padalino, G., Palomba, M., Tamanini, M., 2000. The bentonites in pelotherapy: thermal properties of clay pastes from Sardinia (Italy). Applied Clay Science. Vol 16., p.125-132.

Carretero, M.I., Gomes, C.S.F., Tateo, F., 2006. Clays and human health. In: Bergaya, F., Theng, B.K.G., Lagaly, G

(Eds.) Handbook of Clay Science, Development in Clay Science, vol 1, p.717-741. Chapter 11.5. Elsevier.

Degens, E.T., 1967. Geochemistry of Sediments. Mir., Moscow, p. 217. (Russian)

Degtyarenko, T.V., Mokulkin, R.F., 1997. Biogenic stimulators and immune reactivity. Odessa, Moscow. p.56-70. (Russian)

Dolmaa, G., Ugtakhbayar, O., Tserenpi.1, Sh., 2004. Patent 2444. B01 D11/00, C10G73/00, The extraction method of lipid from mineralized hydrosulfide peloid. pp.12. (Mongolian)

Dolmaa, G., Tserenpil, Sh., Nambar, B., 2008. Healing mud: The classification and the general requirement for sampling and their storages MNS 5849:2008. pp.20. (Mongolian)

Voronkov M.G., Dolmaa G., Sh.Tserenpil., Ugtakhbayar O., 2009 DAN T.426. N4. P.487-490

Drosos, M., Jerzykiewicz, M., Deligiannakis, Y., 2009. H-binding groups in lignite vs. soil humic acids: NICA-Donnan and spectroscopic parameters. Journal of Colloid and Interface Science., Vol 332, p.78-84

D'Souza, F., Bhosle, N.B., 2001.Variation in the composition of carbohydrates in the Dona Paula Bay (west of India) during May/June 1998, Oceanologica Acta 24, p.221-237.

Eglinton., G and Hamilton R.J., 1963. The distribution of alkanes, In:T. Swain (Ed.), Chemical plant taxonomy. Academic press, pp.187-217.

European Chemical Industry Ecology and Toxicology Centre, An assessment of the occurrence and effects of dialkyl ortho-phthalates in the environment. - Brussels Technical Report. 1985. N.19

Ferrand, T., Yvon, J., 1991. Thermal properties of clay pastes for pelotherapy. Applied Clay Science., Vol 6(1), p. $21-38$

Giam, C.S., Atlas, E., Powers, M.A., 1984. Phthalic acid esters. The Hand book of Enviromental Chemistry Y. 3. Part C. Anthropogenic Compounds. Berlin. Springer. Verlag. 67.

Gomes, C., Silva, J., 2007. Minerals and clay minerals in medical geology. Applied Clay Science ., Vol 36, p.4-21.

Cowie, G.L., Hedges, J.I., 1984. Carbohydrate sources in a coastal marine environment, Geochimica et Cosmochimica Acta., Vol 48, p. 2075-2087.

Khodse, V.B., Fernandes, L., Bhosle, N.B., Sardessai S., 2008. Carbohydrates, uronic acids and alkali extractable carbohydrates in contrasting marine and estuarine sediments: Distribution, size fractionation and partial chemical characterization. Organic Geochemistry, Vol 39, p.265-283

Ivanov, B.B., Malakhov, L.M., 1963. Materials on studies of peloids. Mir, Moscow. pp.68. (Russian)

Jamyansan., Ya., Gunbilig, D., Monkhtsetseg, Ts., Selenge, D., 2003. The cannabynoids chemical composition of flax in Mongolia The grant report- UB. p.40-49. (Mongolian)

Mashkovsky, M.D. 1993. Biogenic stimulators. Remedies. Medicine, Moscow, p.173-177. (Russian)

Legido, J.L., Medina, C.M., Mourelle, L., Carretero, M.I. , Pozo, M., 2007. Comparative study of the cooling rates of bentonite, sepiolite and common clays for their use in pelotherapy. Applied Clay Science., Vol 36, p.48-160. 
Maslov O.D., Gustova, M.V., 2004. Multicomponent instrumental gamma activation analysis of soil and other environmental objects. Standard enterprise STP 105-2004, JINR, Dubna, Russia. (Russian)

Manskaya, S.M., Drozdova, T.V., 1964. Geochemistry. Mir, Moscow. Mashkovsky, M.D., 1993. Biogenic stimulators, Remedies. Medicine, Moscow. (Russian)

Mengchang HE, Yehong SHI., Chunye LIN., 2008. Characterization of humic acids extracted from the sediments of the various rivers and lakes in China. Journal of Environmental Sciences Volume 20(11), p.1294-1299.

Meyers P A, Ishiwatari R, 1993. Lacustrine organic geochemistry: an overview of indicators of organic matter

Sources and diagenesis in lake sediments. Org Geochem, Vol 20., p.867-900.

Nelson, D.W and Sommers, L.E., 1996. Total carbon, organic carbon, and organic matter. In: Methods of Soil Analysis, Part II., Ed. Agronomy. Vol 9., p.961-1010.

Puntus, F.A., 1998. Effect of biological productivity and water reservoir flowage on the chemical composition of humic acids and lipids of sapropels Minsk. Nature management., Vol 4, p.8191. (Russian))

Puntus, F.A., Puntus, A., 2008. Humic acids of Pelosilt as prospective biogenic stimulators for Mmdicine and cosmetology use, Proceedings of the $14^{\text {th }}$ International Meeting of the International Humic Substances Society. Sep 14-19, Moscow-Saint Peterburg, Russia, Volume II, p.733-736.

Rui Wang., 2002. Two's company, three's a crowd: can $\mathrm{H}_{2} \mathrm{~S}$ be the third endogenous gaseous transmitter? The FASEB Journal. Vol 16., p.1792-1798.

Sodnom N., Gerbish Sh., Maslov O.D., Gavrilov K.A., Belov A. G., 1989. Determination of Elemental Composition of Coal by Nuclear-Physical Methods. Chemistry Solid Fuel, p.11-15. (Russian)

Shinkarenko, A.L., Milenina, N.L., 1981. Organic matters of healing mud and their role for healing effect on organism, Mud preparation, University of Tomsk, Tomsk. (Russian)

Shustov, L.P., 1996. Extracts of hydrosulfide sticky mud and its application. University of Tomsk, Tomsk. (Russian)

Staples, C.A., Thomas, P.F., Peterson, D.R., 2000. A risk assessment of selected phthalate ester in North American and western European surface waters. Chemosphere., vol 40(8). p.885-891.

Summa, V., Tateo, F., 1998. The use of pelitic raw materials in thermal centres: mineralogy, geochemistry, grain size and leaching tests. Examples from Lucania area (southern Italy). Applied Clay Science. Vol 12, p.403-417.

Summa, V., Tateo, F., 1999. Geochemistry of two peats suitable for medical uses and their behaviour during leaching. Applied Clay Science., Vol 15, p.447-489.

Tateo, F., Ravaglioli, A., Andreoli, C., Bonina, F., Coiro, V., Degetto, S., Giaretta, A., Mencon, O.A., Puglia, C., Summa, V., 2009. The in-vitro percutaneous migration of chemical elements from a thermal mud for healing use. Applied Clay Science., Vol 44, p.83-94.

Tsarfis, P.G., Kiselev V.B., 1990. Healing mud and natural thermoconductor. Visshaya shcola, Moscow, Russia. p.12. (Russian)

Tserenpil, Sh., 2005. The chemical composition of peloids from Lake Bottom. Ph.D. Thesis. UB, Mongolia. (Mongolian)

Vaisfeld, D.N., Galina, V.I, 1996. Introduction of the information-energetic balneo-physiotherapy (facts and hypotheses). Medical reform, balneology and physiotherapy., Vol 1. p. 55 - 62. (Russian)

Veniale, F., Barberis, E., Carcangiu, G., Morandi, N., Setti, M., Tamanini, M., Tessier, D., 2004. Formulation of muds for pelotherapy: effects of "maturation" by different mineral waters. Applied Clay Science., Vol 25, p.135- 148.

Veniale, F., Bettero, A., Jobstraibizer, P.G., Setti, M., 2007. Thermal muds: Perspectives of innovations. Applied Clay Science., Vol 36, p.141-147.

Vulfson, I.V., Zaikin, V.G., Mikaya, A.I., 1985. Mass-spectrometry of organic compounds., Mir, Moscow. p. 210-218 (Russian) 